\title{
Pengaruh Likuiditas, Solvabilitas, dan Profitabilitas terhadap Earning per Share pada Bank Umum yang Terdaftar di Bursa Efek Indonesia
}

Effect of liquidity, solvency, and profitability on earning per share in commercial banks listed on the Indonesian stock exchange

\section{Rizki Muhammad Siddiq}

Program Studi D3 Keuangan dan Perbankan, Politeknik Negeri Bandung

E-mail: rizkimuhammadsiddiq@gmail.com

\section{Setiawan}

Jurusan Akuntansi, Politeknik Negeri Bandung

E-mail: setiawan@polban.ac.id

\section{Ade Ali Nurdin}

Jurusan Akuntansi, Politeknik Negeri Bandung

E-mail: ade.nurdin@polban.ac.id

\begin{abstract}
In conducting this research which aims to find out from the influence of Loan to Deposit Ratio (LDR), Debt to Assets Ratio (DAR), and Return on Assets (ROA) to Earning per Share (EPS) in Commercial Banks listed on the IDX period 2008-2017. In this study the type of data used is secondary data, which is from financial statement data that has been published by the website on the Indonesia Stock. Exchange and the website of each company that will be examined in the period 2008-2017. The total sample used in this study is four bank companies in the banking subsector that have been listed on the Indonesia Stock. Exchange from 2008-2017. The technique that will be used in the way of sampling is by purposive sampling technique is a technique of determining samples with certain considerations. The analysis technique in this study uses panel data regression analysis using the Eviews 10 program tool.
\end{abstract}

Keywords: loan to deposit ratio, debt to assets ratio, return on assets, earning per share

\section{Pendahuluan}

Lembaga-lembaga keuangan khususnya dalam dunia perbankan sudah lama telah mewarnai kegiatan perekonomian negaranya dalam sehari-hari. Keberadaan lembaga bank ini merupakan yang sangat penting di dalam suatu sistem perekonomian yang sudah moderen ini. Sebagai lembaga intermediasi perbankan harus memiliki modal yang sangat besar untuk mencukupi. Dalam mendapatkan modal untuk melakukan kegiatan usahanya bank bisa memperoleh modal tersebut dari utang yang mengandung biaya dalam berupa bunga dan modal seperti saham yang juga mengandung biaya, yaitu berupa dividen (Sukarno \& Syaichu, 2016).

Perusahaan dalam cara menanamkan modalnya ke suatu lembaga yaitu bank, investor bisa melihat langsung dalam kinerja keuangan bank tersebut. Salah satunya adalah dengan rasio Earning Per Share (EPS) atau laba per saham. Pembeli saham biasa umumnya lebih memperhatikan penghasilan per lembar sahamnya karena EPS ini yang nantinya akan mempengaruhi harga saham di pasaran untuk memperoleh capital gain (Rahardjo, 2005). Manajemen yang juga dalam pemegang sahamnya, akan 
selalu berupaya meningkatkan nilai bank tersebut yang di tanamkan modalnya. Semakin meningkatnya dalam kepemilikan oleh seorang manajemen, maka akan menyebabkan manajemen tersebut akan lebih bersikap hati-hati dalam menggunakan utangnya karena mereka juga akan ikut menanggung risiko yang akan menimbulkan dari tindakannya tersebut.

Beberapa faktor yang diduga dapat mempengaruhi rasio Earning Per Share (EPS) adalah rasio profitabilitas yang dapat di perhitungkan dengan daya laba dasar atau Basic Earning Power atau rasio Leverage yang diproksikan dengan rasio Debt To Assets Ratio (DAR). Dalam rasio profitabilitas, dapat mengetahui besarnya earning yang bisa diperoleh oleh suatu bank tersebut, yang akan dibenarkan untuk menarik modal dengan beban tetap atau tidak. Suatu yang memiliki earning yang tetap akan selalu memenuhi kewajiban finansialnya sebagai akibat penggunaan modal asing (Zamri, 2016).

Di dalam rasio profitabilitas ini merupakan suatu usaha atau tindakan yang dilakukan bank untuk memperoleh laba atau ukuran efektivitas pengelolaan manajemen perusahaan. Dalam rasio profitabilitas ini rasio yang diwakilkan adalah Return On Assets (ROA). Rasio ini merupakan rasio perbandingan antara laba sebelum pajak terhadap total aset. Didalam kinerja keuangan suatu bank akan terlihat baik apabila bank tersebut bisa menjaga nilai rasio ini, karena semakin besarnya rasio ini maka dalam tingkat pengembalian yang diharapkan oleh bank akan semakin meyakinkan oleh pemegang saham (Tita, 2011).

Rasio likuiditas ini menunjukan kemampuan perusahaan ini dalam melakukan pembayaran kewajibannya finansialnya dengan segera, rasio ini berguna untuk bisa mengetahui seberapa besar aset perusahaan yang likuid ini yang bisa dapat mengubah menjadi kas untuk membayar tagihan yang tak terduga. Peneliti mengambil salah satu rasio likuiditas ini dengan rasio Loan To Deposit Ratio (LDR). Rasio ini merupakan perbandingan antara seluruh jumlah kredit atau pembiayaan yang diberikan oleh bank dengan dana yang diterima bank (Amanah \& Azizah, 2012).

\section{Kajian Pustaka}

\subsection{Earning per Share}

Earning Per Share (EPS) menunjukan berapa besarnya laba bersih bank yang siap untuk dibagikan untuk semua para pemegang saham. EPS merupakan gambaran dari laba perusahaan, dan hal ini tersaji dalam laporan keuangan sebagai pertanggungjawaban aktivitas perusahaan yang memberikan bagaimana pengelolaan harta principal oleh manajemen (Setiawan dan Mauluddi, 2016). Bagi para investor, Informasi EPS ini merupakan Informasi yang sangat mendasar dan berguna bagi para investor karena bisa menggambarkan prospek earning bank di masa yang akan datang. Semakin tinggi rasio ini suatu perusahaan berarti semakin besar earning yang akan di terima oleh investor dari investasinya tersebut, sehingga bagi perusahaan EPS ini dapat memberikan dampak yang positif terhadap harga sahamnya untuk di pasaran.

\subsection{Loan to Dedeposit Ratio}

Loan to Deposit Ratio (LDR) merupakan beberapa inti penting dalam kelangsungan dalam suatu perusahan terutama pada perusahaan perbankan. Perusahan perbankan ini meruapakan sangat memperhatikan dalam masalah likuiditas karena merupakan dasar kepercayaan masyarakat terhadap kekayaan dan kelancaran serta kemampuan suatu usaha bank, antara lain terletak pada kelancaran lalu lintas yang pembayarannya dalam melayani masyarakat setempat. Kemampuan perusahaan perbankan dalam memberikan kredit kepada nasabah dengan menghasilkan dana pihak ketiga mempunyai pengaruh positif terhadap profitabilitas perusahaan. Kemampuan perusahaan perbankan dalam memenuhi kewajiban jangka pendek ini mampu mengurangi pengeluaranpengeluaran perusahaan yang tidak penting (denda, penalti, dan lain-lain). Sehingga Loan To Deposit Ratio (LDR) perbankan sangat menyokong profitabilitas dari perbankan. 


\subsection{Debt to Assets Ratio}

Menurut Yudiawati \& Indriani (2016), Debt to Assets Ratio merupakan suatu rasio yang menunjukan sejauh mana perusahaan ini yang di bayarkan utangnya tersebut. Debt To Assets Ratio di dapatkan hasil dari perbandingan antara total hutang perusahan dengan total aktivanya. Semakin tinggi DAR menunjukan makin berisiko bank ini karena makin besarnya kewajiban yang di gunakan dalam pembelian asetnya (Prakarsa dan Setiawan, 2018). Jika persuhana ini yng meninjam dalam jmlah besar tidak akan dapat membayar hutangnya. Perusahaan ini akan mengalamai kebangkrutan dan investor akan kehilangan dalam seluruh investasinya. Dapat dkatkan apabla dalam suatu bank lebih banyk dibiayai oleh hutang atau memiliki hutang yang lebh besar dari pada asetnya, maka akan berisiko bagi bank ini dengan yang akn mnculnya dalam ksulitan mengelola keuangannya.

\subsection{Return On Assets}

Menurut Lestari dan Sugiharto (2007:196) Return On Assets (ROA) adalah merupakan rasio yang akan digunakan dalam mengukur untuk kemampuan perusahaan yang akan menghasilkan laba, berasal dari beberapa aktivitas investasinya. Semkin besar ROA ini semakin pula kemungkinan besar dalam tingkat keuntungan yang akan dicapai oleh perusahaan tersebut dan semakin baik dan efisien pula posisi perusahaan tersebut dalam segi mengunakan asetnya (Hijriyani dan Setiawan, 2017). Hal ini menunjuukan akan meingkatkan daya tarik persahaan kepada investor. Penggunaan daya tarik perusahaan akan jadi perusahaan ini akan banyak diminati oleh suatu pemodal. Karena dalam pengembalian ini akan semakin besar, hal ini kita dapat lihat bahwa dampak dari harga saham dari perusahaan tersebut di pasarannya akan semakin meingkat sehinga rasio ini akan berpengaruh terhadap harga saham bank.

Dapat disimpulkan bahwa ROA ini bisa mengukur sejauh mana dalam kemampuan perusahaanya bisa menghasilkan keuntungan yang menjadi hak pemegang saham atas modal yang di investasikan oleh pemodalnya. Oleh karena itu bisa meberikan informasi yang baik pula. Semakin baik kondisi perusahaan ini dalam memperoleh labanya makan akan bisa dalam pengembalian investasi ini yang telah ditanamkan oleh investornya.

\subsection{Hipotesis Penelitian}

Menurut Sugiyono (2009) hipotesis ini merupakan suatu jawaban sementra terhadap beberapa rumusan masalah dalam penelitian yang telah dinyatakan dalam bentuk pertanyaan, maka hipotesis yang dilakukan dalam penelitian ini adalah sebagai berikut:

$\mathrm{H}_{1}$ : Rasio Likuiditas (Load To Deposit Ratio) berpengaruh positif terhadap Earning Per Share (EPS). $\mathrm{H}_{2}$ : Rasio Solvabilitas (Debt To Assets Ratio) berpengaruh negatif terhadap Earning Per Share (EPS). $\mathrm{H}_{3}$ : Rasio Profitabilitas (Return On Assets) berpengaruh positif terhadap Earning Per Share (EPS)

Sehingga dapat digambarkan paradigma penelitian sebagai berikut:

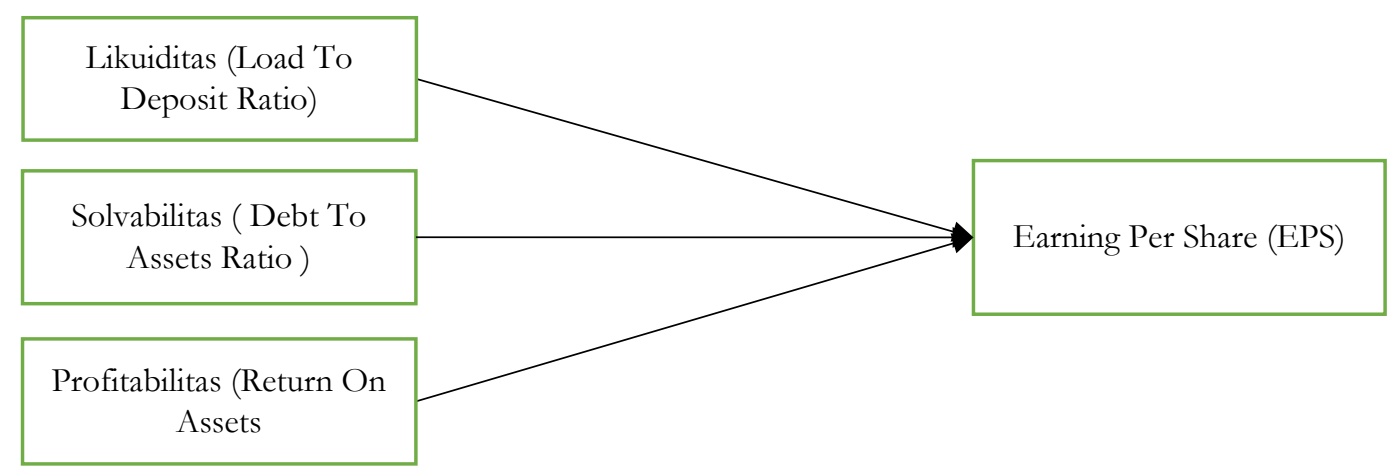

Gambar 1. Paradigma Penelitian 


\section{Metode Penelitian}

Metode yang digunakan dalam penelitian ini yaitu dengan metode deskriptif ialah metode yang digunakan dalam menunjukan atau dalam menganalisis suatu hasil penelitian tetapi tidak dapat digunakan dalam menentukan kesimpulan lebih luas. Tujuan dari penelitian deskriptif ini yaitu untuk membuat deskripsi secara sistematis, akurat dan faktual trhasap sifat-sifat, fakta-fakta dan hubungan antar fenomena yang diteliti. Berdasarkan tujuan penelitian ini, metode ini digunakan untuk mengetahui gambaran, hubungan likuiditas, solvabltas, profitablitas terhadap EPS suatu bank (Sugiyono, 2009:21).

Penilitian ini menggunakan analiss data model regrsi data panel, karena data yang gunakan dalam pnelitian ini memiliki sampel dari banyak bank, dan dalam periode tahun yang berkelanjutan. Alat bantu dalam mengelola data peneli ini yaitu dengan cara menggunakan software Eviews 10. Dibalik dalam penggunaan sofware ini terdapat beberapa alasan, diantarnya:

1) Alat sodftware ini memilki tampilan untuk menginput data panel, merupakan gabungan data cross scrtion dan data time series yang mampu mnyediakan data yg lebih banyak sehingga akan menghaslkan derajat kebebasan yang lebih besar.

2) Mengbungkan informasi data dari cross section dan time swries yg dapat mengatasi masalah yg timbul ketika ada masalah penghilangan dalam isi variabel penelitian ini.

\section{Hasil dan Pembahasan}

\subsection{Statistik Deskriptif}

Untuk melihat sebaran data, berikut disajikan hasil pengujian deskriptif statistik pada tabel di bawah ini.

Tabel 1. Deskriptif Statistik Variabel Penelitian

\begin{tabular}{|l|r|r|r|r|}
\hline & \multicolumn{1}{c|}{ LDR } & DAR & ROA & EPS \\
\hline Mean & 78.6748 & 86.6158 & 3.11025 & 531.73 \\
\hline Median & 81.28 & 87 & 2.9 & 486.5 \\
\hline Maximum & 92.1 & 92 & 5.15 & 1071.51 \\
\hline Minimum & 50.3 & 79 & 1.1 & 23.28 \\
\hline Std. Dev. & 11.2411 & 3.50615 & 1.04682 & 279.323 \\
\hline Skewness & -0.9815 & -0.2642 & 0.14764 & 0.10483 \\
\hline Kurtosis & 3.00578 & 2.09001 & 2.27016 & 2.16301 \\
\hline Jarque-Bera & 6.42287 & 1.84533 & 1.0331 & 1.24086 \\
\hline Probability & 0.0403 & 0.39746 & 0.59657 & 0.53771 \\
\hline Sum & 3146.99 & 3464.63 & 124.41 & 21269.2 \\
\hline $\begin{array}{l}\text { Sum Sq. } \\
\text { Dev. }\end{array}$ & 4928.17 & 479.432 & 42.7377 & 3042835 \\
\hline Observations & 40 & 40 & 40 & 40 \\
Sumber: Output Eviews 10 & & & & \\
\hline
\end{tabular}

Berdasarkan tabel 1 di atas dapat dijelaskan sebagai berikut:

1) Earning Per Share (EPS)

Berdasarkan dari hasil tabel di atas 4.2 dapat kita ketahui bawah rasio EPS ini memiliki data dengan angkat minimun 23,28, sedangkan akan maximumnya adalah 1071,51, yang memiliki nilai rata-ratanya sebesar 531,73 dan jga mempunyai standar deviasinya adalah 279,323.

2) Loan To Deposit Ratio (LDR) 
Berdasarkan dari hasil di atas 4.2 dapat kita ketahui bahwa rasio EPS ini memiliki data dengan angksat mimimum 50,3, sedangkan angksa maximnya adalah 92,1 yang memiliki nilai rataratanya sebesar 78,6748 dan jga mempunyai standar deviasinya adalah 11,2411.

3) Debt To Assets Ratio (DAR)

Berdasarkan dari hasil di atas 4.2 dapat kita ketahui bahwa rasio EPS ini memiiki data dengan angkasat mimumnya 79, sedangkan angka terbesar maximum adalah 92, dengan nilai rata-rata 86,6158 dan juga mempunyai standar deviasinya adalah 3,50615.

4) Return On Assets (ROA)

Berdsarkan dari hasil dii atas 4.2 dapat kita ktahui bahwa rasio EPS ini memiliki data dengan angkasat minimumnya 1,1 sedangkan angkat terbesar maximumnya adalah 5,15, dengan nilai raya-rata adalah 3,11025 dan standar deviasi sebesar adalah 1,04682.

\subsection{Penentuan Model Regresi}

\section{Uji Chow}

Setelah peneliti melakukan penelitiannya, dapat kita gunakan dengan metode eviews 10 , berikut hasil dari uji chow dengan menggunakan metode model common effect atau fixed effect sebagai berikut:

Tabel 2. Uji Chow

Redundant Fixed Effects Tests

Equation: Untitled

Test cross-section fixed effects

\begin{tabular}{lrrr}
\hline \hline Effects Test & Statistic & d.f. & Prob. \\
\hline \hline Cross-section F & 0.948857 & $(3,33)$ & 0.0283 \\
Cross-section Chi-square & 3.309615 & 3 & 0.0463 \\
\hline \hline
\end{tabular}

Berdasarkan hasil penelitian yang terdapat pada tabel di atas 2 nilai chi-square adalah 0,0463 nilai ini merupakan bahwa hasil ini memiliki nilai kecil dari alpha 0,05 dari hasil ini , dapat kita simpulkan bahwa model ini merupakan metode yang tepat untuk regresi data panel fixed effect Model.

\section{Uji Hausman}

Berikut ini merupakan dari hasil uji hasuman test dengan meggunakan metode fixed effect atau random effect yang paling tepat dalam penelitian ini, di dapatkanlah hasil metode ini sebagai berikut:

\section{Tabel 3 Uji Hausman}

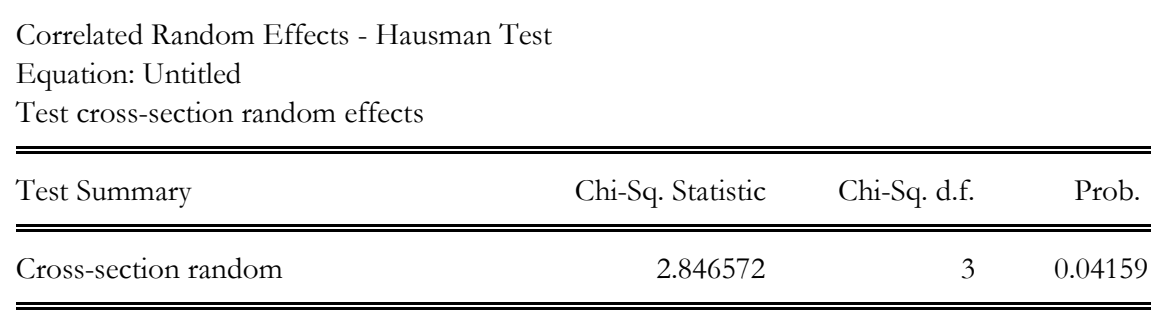

Berdasarkan hasil ini kita dapat mengetahui pada tabel 3 diperoleh nilai prob 0,04159 hal ini pneliti bisa lihat bahwa nilai ini lebih kecil dari nilai alphanya sebesar 0,05 . Oleh karena itu hipotesis yang relah dirumuskan maka $\mathrm{H}_{\circ}$ ditolak dan $\mathrm{H}_{1}$ diterima sehingga peneliti bisa simpulkan bahwa metode ini merupakan yang tepat untuk dijadikan dalam penelitian ini adalah fixed effect model. 


\subsection{Pengujian Asumsi Klasik}

\section{Uji Normalitas}

Dalam uji normalitas ini merupakan sebuah uji yang peneliti lakukan yang bertujuan untuk menilai sebaran data pada sebuah kelompok data atau variabel.

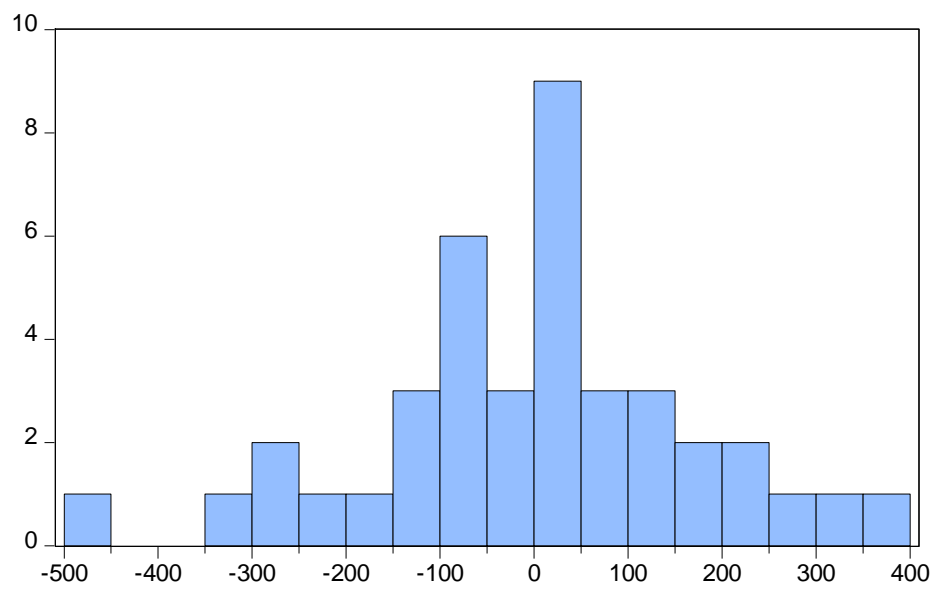

$\begin{array}{ll}\text { Series: Standardized Residuals } \\ \text { Sample } 20082017 \\ \text { Observations } & 40 \\ & \\ \text { Mean } & -9.95 \mathrm{e}-15 \\ \text { Median } & 12.55767 \\ \text { Maximum } & 361.9740 \\ \text { Minimum } & -463.3097 \\ \text { Std. Dev. } & 173.1138 \\ \text { Skewness } & -0.246355 \\ \text { Kurtosis } & 3.276804 \\ & \\ \text { Jarque-Bera } & 0.532308 \\ \text { Probability } & 0.766321\end{array}$

Gambar 2. Hasil Uji Normalitas

Berdasarkan hasil tabel di atas 2 bahwa uji ini memiliki niai dari jarque -beta 0,532308 yang memiliki nilai lebih dari nilai aplhanya sebesar 0,05 . Hasil uji ini dapat menunjukan bahwa peneliti ini terbebas masalah normalitas atau dapat dikatakan data ini memiliki data yang normal.

\section{Uji Multikolinearitas}

Dalam uji multikolinearitas ini peneliti bisa melihat situaisi yang dapat menunjukan adanya korelasi atau hubungan kuat antara dua variabel yang bebas atau lebih di dalam suatu model regresi berganda.

\section{Tabel 4. Hasil Uji Multikolinearitas}

\begin{tabular}{|c|c|c|c|}
\hline $\begin{array}{l}\text { Variance Inflation } \mathrm{F} \\
\text { Date: } 07 / 20 / 19 \\
\text { Sample: } 140 \\
\text { Included observatio }\end{array}$ & & & \\
\hline Variable & $\begin{array}{c}\text { Coefficient } \\
\text { Variance }\end{array}$ & $\begin{array}{c}\text { Uncentered } \\
\text { VIF }\end{array}$ & $\begin{array}{c}\text { Centered } \\
\text { VIF }\end{array}$ \\
\hline C & 1209964. & 1372.376 & NA \\
\hline LDR & 12.75072 & 91.29895 & 1.781808 \\
\hline DAR & 120.7259 & 1028.935 & 1.641223 \\
\hline ROA & 1123.125 & 13.68415 & 1.361068 \\
\hline
\end{tabular}

Dari hasil tabel di atas 4 dapat terlihat bahwa terdapat masalah multikolinearitas antara variabel independen karena memiliki nilai setiap variabelnya yang lebih besar dari 0,8 .

\section{Uji Heteroskedastisitas}

Di dalam uji dapat mengakibartkan pendugaan ini dalam parameternya tidak efisien sehingga tidak mempunyai ragam minimu. Karena pendugaan parameter ini akan dianggap karena memiliki 
ragam yang minimum, jadi ragam ini bersifat konstant atau disebut juga bhwa asumsi homoskedastisitas terpenuhi, salah satu usaga untuk mengatasi heteroskedastisitas ini dapat dilakukan dengan mengtransformasikan variabelnya, baik variabel bebas, variabel tidak bebas, maupun keduanya afar asumsi homoskedastisitas terpenuhi.

Tabel 5. Hasil Uji Heterokedastisitas

Heteroskedasticity Test: Breusch-Pagan-Godfrey

\begin{tabular}{llll}
\hline \hline F-statistic & 0.487635 & Prob. F(3,36) & 0.6930 \\
Obs*R-squared & 1.561978 & Prob. Chi-Square(3) & 0.6680 \\
Scaled explained SS & 1.221601 & Prob. Chi-Square(3) & 0.7478 \\
\hline \hline : Output Eviews 10 & & &
\end{tabular}

Dari hasil pengujian pada tabel 5 di atas menunjukan haisil dari uji white dengan memiliki nilai chi-square lebih dari nilai alpha yaitu 0,05 . Hal ini dapat peneliti lihat bahwa data ini terbebas dari unsur heteroskedastisitas.

\section{Uji Autokorelasi}

Autokorelasi ini merupakan kesalahan dari asumsi non-autokorelasi. Hal ini disebabkan karena adanya korelasi antar gangguan atau eror yang terdapat pada beberapa pengamtannya. Uji ini juga dapat dikatkan memiliki kesalahan dari gangguan periode tertntu berkorelasi dengan gangguan atau memiliki eror dari periode sebelumnya.

Tabel 6. Hasil Uji Autokorelasi

Breusch-Godfrey Serial Correlation LM Test:

\begin{tabular}{llll}
\hline \hline F-statistic & 3.903231 & Prob. F(2,34) & 0.0298 \\
Obs*R-squared & 7.469143 & Prob. Chi-Square(2) & 0.0239 \\
\hline \hline
\end{tabular}

Sumber: Output Eviews 10

Dari hasil ini dapat peneliti tunjukan tdak tedapat adanya autokorelasi, hal ini dapat peneliti lihat bahwa memiliki niai prob*R sebesar 7,469143 lebih besar dari hasil nilai alpha 0,05 . maka dapat disimpulkan bahwa model peneltiain ini terbebas dari masalah autokorelasi.

\subsection{Pengujian Hipotesis dan Interpretasi}

Tabel 7. Hasil Pengujian Fixed Effect Model

Dependent Variable: EPS

Method: Panel Least Squares

Date: 07/20/19 Time: 13:01

Sample: 20082017

Periods included: 10

Cross-sections included: 4

Total panel (balanced) observations: 40

\begin{tabular}{crrrr}
\hline \hline Variable & Coefficient & Std. Error & t-Statistic & Prob. \\
\hline \hline C & 971.9080 & 1441.782 & 0.674102 & 0.5049 \\
LDR & 10.83826 & 3.776809 & 2.869686 & 0.0071 \\
DAR & -19.12217 & 13.74594 & -1.391114 & 0.1735 \\
ROA & 116.8414 & 60.35899 & 1.935775 & 0.0615 \\
\hline \hline
\end{tabular}


Effects Specification

\begin{tabular}{lrll}
\hline \hline Cross-section fixed (dummy variables) & & \\
\hline \hline R-squared & 0.615895 & Mean dependent var & 531.7298 \\
Adjusted R-squared & 0.546058 & S.D. dependent var & 279.3231 \\
S.E. of regression & 188.1946 & Akaike info criterion & 13.47046 \\
Sum squared resid & 1168768. & Schwarz criterion & 13.76601 \\
Log likelihood & -262.4092 & Hannan-Quinn criter. & 13.57732 \\
F-statistic & 8.819007 & Durbin-Watson stat & 1.218289 \\
Prob(F-statistic) & 0.000009 & & \\
\hline \hline
\end{tabular}

Berdasarkan dari hasil pengujian diatas maka dapat peneliti peroleh rumus ini dengan regresi data secara keseluruhan dari variabel-variabel yang. Adapun rumusnya sebagai berikut:

$$
Y=971,9080+10,83826 * \mathrm{LDR}-19,12217 * 8414 * \mathrm{ROADAR}+116,
$$

Berdasarkan dari hasil tabel diatas 8 didapatkan nilai adjusted R-square-nya sbesar 0,546058. Nilai tersebut menunjukan bahwa hasil dari 54,6058 persen Earning Per Share (EPS) dapat dijelaskan oleh variabel independen ini yang terdiri dari Loan To DepositRatio (LDR) Debt To Assets Ratio (DAR) dan Return On Assets (ROA) sedangkan hasil sisanya 45,3942 persen dijelaskan oleh beberapa variabel lain yang tidak dijelaskan pada penelitian ini.

Setelah dilakukan dalam pengujian pada model regresi ini dengan menggunakan model fixed effect, didapatkan hasil estimasi yang menunjukan nilai probability dari variabel independen pada penelitian ini. Menginterpretasikan bahwa nilai probability dari ketiga variabel hanya variabel Debt To Assets Ratio (DAR) yang memiliki nilai 0,1735 dan Return On Assets (ROA) yang memiliki nilai 0,0615 yang artinya lebih besar dari nilai alpha 0,05.

Berdasarkan dari tabel 8 di atas, uji F Earning Per Share (EPS) diperoleh nilai prob (F-Statistic) sebesar 0.000009 lebih kecil dari nilai tingkat kesalahan atau standar error (alpha) 0.05. Sehingga dapat disimpulkan bahwa model regresi layak digunakan untuk menjelaskan pengaruh Loan To Deposit Ratio (LDR), Debt To Assets Ratio (DAR), Return On Assets (ROA) terhadap Earning Per Share (EPS).

\subsection{Pembahasan}

\section{Pengaruh Loan To Deposit Ratio (LDR) terhadap Earning Per Share (EPS)}

Berdasarkan tabel 7 Uji $\mathrm{t}$ diperoleh hasil coefficient LDR sebesar 10,83826 dengan nilai profitabilitas 0,0071 yang mana nilai probabilitas ini lebih kecil dibandingkan dengan nilai alpha sebesar 0,05. Dari hasil tersebut dapat dapat disimpulkan bahwa $\mathbf{H}_{1}$ diterima, karena LDR memiliki pengaruh yang signifikan terhadap variabel dependen EPS. Data sampel yang digunakan berhasil membuktikan adanya hubungan tersebut.

Dari hasil penelitian ini menurut Clarensia (2011) dapat disimpulkan bahwa likuiditas berpengaruh terhadap Earning Per Share (EPS). Rasio likuiditas menunjukan sejauh mana aktiva lancar menutupi kewajiban-kewajiban lancar. Semakin besar perbandingan aktiva lancar dengan utang lancar semakin tinggi. Dengan demikian, apabila kemampuan likuiditas perusahaan itu baik, investor tidak perlu mencemaskan apakah model yang mereka tanam di perusahaan tersebut akan kembali dan memberikan keuntungan untuk mereka atau tidak. Karena jika suatu perusahaan yang tingkat likuiditasnya tidak baik, kecenderungannya dijauhi oleh investor karena takut dana yang mereka diinvestasikan tidak kembali dan mengakibatkan kerugian bagi investor.

Pengaruh Debt To Assets Ratio (DAR) terhadap Earning Per Share (EPS) 
Berdasarkan tabel 7 Uji t diperoleh hasil coefficient DAR sebesar -19,12217 dengan nilai profitabilitas 0,1735 yang mana nilai profitabilitas nya lebih besar dari nilai alpha 0,05 . Maka $\mathrm{H}_{2}$ ditolak. Hal ini menunjukan bahwa Debt To Assets Ratio (DAR) tidak signifikan terhadap variabel dependen Earning Per Share (EPS), data sampel yang digunakan tidak berhasil membuktikan adanya hubungan tersebut.

Dari hasil penelitian ini menurut Ika Hermawati (2008) dapat disimpulkan bahwa solvabilitas tidak berpengaruh signifikansi terhadap Earning Per Share (EPS). Rasio solvabilitas adalah untuk menilai kemampuan perusahaan untuk membayar seluruh kewajibannya, baik jangka pendek maupun jangka panjang apabila perusahaan dibubarka. Semakin tinggi solvabilitas, perusahaan harus semaksimal mungkin meningkatkan labanya agar mampu membiayai dan membayar utang. Hal ini konsisten dalam penelitianya bawha Debt To Assets Ratio (DAR) berpengaruh signifikansi terhadap Earning Per Share (EPS).

\section{Pengaruh Return On Assets (ROA) terhadap Earning Per Share (EPS)}

Berdasarkan tabel 7 Uji t diperoleh hasil coefficient Retunr On Assets (ROA) sebesar 116,8414 dengan nilai profitabilitas 0,0615 yang mana nilai profitabilitasnya lebih besar dari alpha 0,05 , maka $\mathrm{H}_{3}$ ditolak. Hal ini menunjukan bahwa Return On Assets (ROA) tidak signifikansi terhadap Earning Per Share (EPS) data sampel yang digunakan tidak berhasil membuktikan adanya hubungan tersebut.

Dari hasil penelitian ini menurut Indah Nurmalasari (2009) Return On Assets (ROA) menunjukan kemampuan perusahaan dalam menghasilkan laba dari aktiva yang dipergunakan. ROA diperoleh dari rasio antara Earning After Tax dengan total aktiva. Dengan demikian semakin tinggi ROA suatu perusahaan makan nilai aset perusahaan semakin tinggi karena banyak diminati oleh para investor. Hal ini dapat disebabkan karena jika perusahaan bisa meraih profit atau keuntungan yang bagus disetiap periode, para investor tidak perlu mengkhawatirkan perusahaan tersebut akan merugi atau bahkan bankrut. Sehingga, keuntungan atau profit yang didapat oleh perusahaan dapat dinikmati juga oleh para investor dan membuka kemungkinan datangnya investor-investor baru lagi yang ingin menanamkan modal mereka disana yang dapat meningkatkan harga pasar saham perusahaan tersebut.

\section{Pengaruh Load To Deposit Ratio (LDR), Debt To Assets Ratio (DAR), Return On Assets (ROA) Terhadap Earning Per Share}

Berdasarkan hasil pengujian pada tabel 7 uji F diperoleh hasil probability F sebesar 0,000009 lebih kecil dari pada nilai alpha sebesar 0,05 maka dapat disimpulkan bahwa dari ketiga variabel independen (Loan To Deposit Ratio, Debt To Assets Ratio, dan Return On Assets) secara simultan memiliki pengaruh yang signifikan terhadap variabel dependen yaitu Earning Per Share (EPS).

Maka dapat disimpulkan bahwa variabel Loan To Deposit Ratio, Debt To Assets Ratio, dan Return On Assets secara simultan atau secara bersama-sama berpengaruh signifikansi terhadap variabel dependen yaitu Earning Per Share (EPS). Jika perusahaan mencapai prestasi yang baik, maka EPS perusahaan tersebut akan banyak diminati oleh para investor. Prestasi baik yang dicapai perusahaan dapat dilihat di dalam laporan keuangan yang dipublikasikan oleh perusahaan (emiten). Untuk menilai kondisi keuangan dan prestasi perusahaan, analisis keuangan memerlukan beberapa tolak ukur. Tolak ukur yang sering dipakai adalah rasio keuangan. Dengan demikian, perusahaan yang mempunyai rasio lukuiditas, solvabilitas dan profitabilitas yang baik cenderung mempunyai EPS yang baik pula dan ini yang dijadikan acuan atau tolak ukur bagi para investor untuk melakukan investasi pada perusahaan tersebut. Karena tidak ada satu investor pun yang menginginkan kerugian dalam setiap investasi yang mereka jalani.

Hal ini konsisten dengan penelitian yang dilakukan Susanto (2012) yang dalam penelitiannya menunjukan bahwa adanya pengaruh Loan To Deposit Ratio, Debt To Assets Ratio, dan Return On Assets 
secara serentak terhadap Earning Per Share maka $\mathrm{H}_{4}$ diterima.

\section{Penutup}

Berdasarkan dari hasil penelitian mengenai pengaruh Loan To Deposit Rasio (LDR), Debt To Assets Ratio (DAR) dan Return On Assets (ROA) terhadap Earning Per Share (EPS) pada Bank Umum yang terdaftar di BEI periode 2008-2017 penulis akan menarik kesimpulan berdasarkan identifikasi masalah yang telah dipaparkan dan telah dilakukan pengujian menggunakan alat analisis Eview 10 sehingga didapat beberapa kesimpulan sebagai berikut:

1) Berdasarkan dari hasil penelitian yang telah dilakukan pada bab sebelumnya, maka dapat disimpulkan bahwa Loan To Deposit Ratio (LDR) berpengaruh secara signifkansi terhadap Earning Per Share (EPS) karena memiliki nilai signifikansi kurang dari alpha 0,05, sebesar 0,0071.

2) Berdasarkan dari hasil penelitian Debt To Assets Ratio (DAR) tidak berpengaruh secara signikansi terhadap Earning Per Share (EPS) karena memiliki nilai signifikansi lebih dari alpha $=0,05$.

3) Berdasarkan dari hasil penelitian Return On Assets (ROA) tidak berpengaruh secara signifikansi terhadap Earning Per Share (EPS) karena memiliki nilai signifikansi lebih dari alpha = 0,05.

4) Loan To Deposit Rasio (LDR), Debt To Assets Ratio (DAR) dan Return On Assets (ROA) memiliki pengaruh secara simultan terhadap Earning Per Share (EPS).

Berdasarkan pemaparan hasil penelitian dan kesimpulan, berikut saran yang dapat di sampaikan peneliti :

1) Bagi calon investor harap untuk berhati-hati dalam melakukan investasi terutama bagi investor yang masih pemula.

2) Bagi para investor harap untuk melakukan konsultasi pada pihak broker yang mengerti dan memahami mengenai laporan keuangan dan lainnya.

3) Bagi peneliti selanjutnya, disarankan untuk menambahkan lagi rasio keuangan dan tahun periode selanjutnya sehingga dapat diperoleh gambaran yang lebih jelas, juga mencoba melakukan analisis dengan menggunakan alat analisis yang berbeda sesuai dengan perkembangan teknologi dengan metode yang berbeda pula agar hasil yang diperoleh lebih kuat dan lebih bervariasi.

\section{Daftar Pustaka}

Amanah, R., \& Azizah, D. F. (2012). Pengaruh Rasio Likuiditas dan Rasio Profitabilitas Terhadap Harga Saham ( Studi pada Perusahaan Indeks LQ45 Periode 2008-2012 ), 12(1).

Ghozali, Imam. (2001). Aplikasi Analisis Multivariate Dengan Program SPSS. Semarang: Badan Penerbit Universitas Dipenogoro.

Hijriyani, N. Z., \& Setiawan, S. (2017). Analisis Profitabilitas Perbankan Syariah di Indonesia sebagai Dampak Dari Efisiensi Operasional. Jurnal Kajian Akuntansi, 1(2), 194-209

Lestari, M.I., dan Sugiharto, T. (2007). Kinerja Bank Devisa dan Bank Non Devisa dan faktor-faktor yang mempengaruhinya. PESAT Vol2.

Prakarsa, R. A., \& Setiawan, S. (2018, October). Pengaruh Profitabilitas, Leverage, Dan Ukuran Perusahaan Terhadap Praktik Perataan Laba (Studi Pada Perusahaan Keuangan Sub Sektor Perbankan Yang Terdaftar Di Bursa Efek Indonesia Periode 2015-2017). In Prosiding Industrial Research Workshop and National Seminar (Vol. 9, pp. 719-727).

Rahardjo, Budi. (2005). Laporan Keuangan Perusahaan : Membaca, Memahami dan Menganalisis. UGM. Yogyakarta.

Santoso, Singgih. (2004). Mengatasi Berbagai Masalah Statistik dengan SPSS Versi11.5. Jakarta: Elex Media Komputindo. 
Santoso, Singgih. (2010). Statistik Parametrik, Konsep dan Aplikasi dengan SPSS. Cetakan Pertama, PT. Elex Media Komputindo, Jakarta. PT.Gramedia, Jakarta.

Santoso, Singgih. (2012). Panduan lengkap SPSS versi 20. Jakarta: PT.Elex Media Komputindo Sugiyono. (2009). Statistik untuk penelitian. CV.ALFABETA:Bandung.

Setiawan \& Hasbi Assidiki Mauluddi. (2016). Kinerja Perusahaan: Studi Pengaruh Corporate Governance Melalui Konservatisme Akuntansi pada Perusahaan yang Terdaftar di Jakarta Islamic Index. Account Jurnal Akuntansi, Keuangan dan Perbankan, 1(5), 368-374.

Sugiyono. (2014). Metode Penelitian Pendidikan Pendekatan Kuantitatif, Kualitatif Dan R\&D. Bandung: Alfabeta.

Sukarno, K. W., \& Syaichu, M. (2016). Analisis Faktor-Faktor Yang Mempengaruhi Kinerja Bank Umum Di Indonesia. Jurnal Studi Manajemen \& Organisasi, 3(2016), 46-58.

Tita, D. (2011). Pengaruh Rasio Keuangan, Pertumbuhan Penjualan Dividen terhadap Harga Saham. Jurnal Bisnis Dan Akuntansi, 13(1), 57-66.

Yudiawati, R., \& Indriani, A. (2016). Analisis Pengaruh Current Ratio , Debt To Total Assets Ratio, Total Assets Turnover, dan Sales Growth Ratio Terhadap Kondisi Financial Distress ( Studi Kasus Pada Perusahaan Manufaktur yang Terdaftar di BEI Tahun 2012-2014 ). Diponegoro Journal Of Management, 5(2), 1-13.

Zamri, N. A. (2016). Nurul Amaliah Zamri, et.al., Pengaruh Rasio Profitabilitas....., 2(01), 77-90 